\title{
对建筑工程电气安装施工质量管理分析
}

陈荣华 ${ }^{1}$ 江碧道 ${ }^{2}$

1 浙江雷愽人力资源开发有限公司派驻桐庐电力开发有限公司 2 浙江富泰建设有限公司

DOI:10.32629/btr.v3i3.2935

[摘 要] 城市化建设进程的不断推进,促进了建筑业快速发展, 同时建筑工程施工也越来越多, 而电气工程施工质量作为建筑项目工程管理的关 键内容, 其对建筑项目可靠运行具有重要影响, 基于此, 本文阐述了建筑电气工程施工的主要特征以及建筑电气施工存在的主要问题, 对建筑电气 工程施工的质量管理进行了探讨分析。

[关键词] 建筑电气工程; 施工; 特征; 问题; 质量管理

电气工程施工质量对于保证建筑工程安全运行非常关键, 因此为了保 障建筑电气工程建设的顺利开展, 以下就建筑电气工程施工质量管理进行 了探讨分析。

\section{1 建筑电气工程施工的主要特征}

1. 1 隐蔽性特征。基于电气工程施工的特点, 其大部分施工都需要在 墙体内开展, 使得电气工程项目施工具有隐蔽性特征。导致建筑电气工 程施工过中, 很难及时发现存在的相关施工问题。所以在建筑电气工程 施工过程中, 为了保障电气工程施工质量, 必须严格隐蔽电气工程施工 质量控制。

1. 2施工质量控制范围比较广。随着科技的进步发展, 使得建筑电气工 程施工日益变得复杂, 同时现代建筑电气工程项目施工也越来越多, 包括 诸多施工环节, 并且相关环节之间的联系越来越紧密, 其中电气系统中的 不同子系统, 它们不仅存在相互交叉的特点, 还能够独立运行。通常现代建 筑电气工程的施工主要有配电、给排水、照明、监控等项目工程的施工, 并且这些项目工程联系比较密切, 使得现代建筑电气工程施工质量控制具 有广泛性特征。在其施工质量管理过程中, 要求电气工程的设计与施工方 进行有效沟通, 从而各个环节的施工质量进行管理。并且由于现代建筑电 气工程的施工工序存在施工周期长的特点, 需要对不同工序质量进行开展 管理。

\section{2 建筑电气工程施工存在的主要问题}

2. 1 管理制度问题。建筑工程在开展施工时必须按照设计图纸组织施 工, 但是目前部分企业的施工班组在组织施工时, 未组织施工图纸会审即 组织施工, 造成施工过程的质量差错, 影响施工进度, 甚至返工。由于部分 设计单位缺乏相关专业的工作对接、校对工作不认真, 因此设计质量从源 头上就埋下了安全隐患, 以上情况是建筑电气施工质量缺陷的原因之一。

2. 2施工图纸及材料质量问题。(1) 施工图纸问题。建筑电气工程施工 过程中, 必须结合电气工程施工图纸开展施工, 假如电气工程施工图纸存 在问题, 将严重影响电气工程质量。目前在建筑电气工程施工时, 由于诸多 因素的影响, 导致电气工程施工图纸质量问题。第一, 很多设计院为了降低 成本, 对设计师经验的要求不高, 导致施工图纸存在质量问题。第二, 电气 工程施工图纸设计前, 未能有效勘察电气工程施工现场实际。第三, 基于现 代建筑电气工程项目比较多, 使得设计工作任务比较重, 同时施工图纸设 计时间比较短, 从而影响施工图纸质量。第四, 电气工程施工图纸设计完成 以后, 必须对其开展严格审核, 但是由于对审核工作没有充分重视, 导致施 工图纸存在质量问题。(2) 材料质量问题。电气工程施工过程中的施工材 料非常重要, 很多材料商家为了追求经济利益, 对材料进行偷工减料。而且 建筑企业的相关人员采购材料时, 购买劣质材料, 验收人员在监督方面没
有严格把关, 一旦劣质材料投入使用当中, 会给施工质量带来极大的影响。

\section{3 建筑电气工程施工的质量管理分析}

3.1 提升施工质量意识。基于不同因素的影响, 使得建筑电气工程施工 过程中容易出现质量问题, 这些问题存在的主要原因就是相关施工人员缺 乏质量意识。因此要求提高电气从业人员的质量意识, 在电气工程施工前, 要对施工单位进行资质评定, 保证其符合施工的要求。同时, 要强化安装人 员的施工责任感, 制定完善的施工规范和流程, 确保他们按照要开展施工 工作。

3. 2 建立科学的管理制度。要想完成一个规范有序质量达标的工程, 就必须先编写好项目计划好项目计划, 然后按施工规范和图纸编制切实可 行的施工组织然后按施工规范和图纸编制切实可行的施工组织设计, 具体 包括专项施工方案, 制定操作规程, 施工图会审, 施工技术交底, 安全施工 技术交底, 各工种对口检查, 工序交接, 工作计划等工种制度, 通过建立健 全各项管理制度, 确保施工过程的每一个环节都具有前瞻性、可行性、可 操作性。

3. 3 科学规划电气工程。现代建筑电气工程施工比较复杂, 因此在电气 工程施工前要合理对其进行规划, 施工图纸是重要参考依据, 但不是唯一 依据, 在实际的电气工程施工过程中, 要结合现场实际开展工作。并要严格 按照施工图纸要求进行作业。另外还要结合工程具体实际, 保证工程方案 的标准性和合理性, 从而保障电气工程施工的有效性。

3. 4 加强施工材料设备质量管理。电气工程施工材料设备要求非常严, 需要保障施工材料设备与国家标准要求相符。因此在施工材料设备质量的 控制过程中, 需要提升监理人员的监管意识, 并且需要对施工材料设备质 量进行检查, 对施工材料设备与国家标准不符的静止入场, 从而可以从根 本上杜绝质量问题。

\section{4 结束语}

综上所述, 建筑电气工程施工过程中, 由于受到诸多因素影响, 使得建 筑电气工程施工存在诸多的问题, 导致电气工程施工质量未能达到相关标 准要求, 因此为了保障建筑电气工程施工质量, 需要就其存在的问题, 采取 相应的措施, 从而有效保障建筑工程安全运行。

\section{[参考文献]}

[1]王欣.略谈现代建筑电气安装工程质量控制技术要点[J].建材与装 饰,2016(27):19-20.

[2]石国良.建筑电气工程施工技术与质量控制 [J].科学导 报,2018(07):59.

[3] 陈刚. 现代建筑电气安装工程质量控制技术分析 [ J]. 科技 风,2019(6):173. 